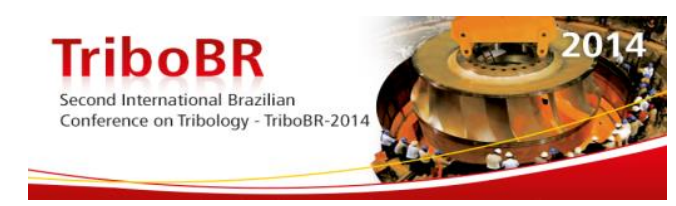

\title{
NIOBIUM CARBIDE (NbC) AS WEAR RESISTANT HARDMETAL IN OPENED AND CLOSED TRIBOSYSTEMS*
}

\author{
Mathias Woydt ${ }^{1}$ \\ Hardy Mohrbacher ${ }^{2}$
}

\begin{abstract}
The tribological and mechanical properties of binderless and metal-bonded niobium carbides (8 or 12 vol.- $\%$ of Cobalt, 12 vol.- $\%$ of $\mathrm{Fe}_{3} \mathrm{Al}$ ) are presented. Rotating disks made of niobium carbide bearing hard metals were mated against alumina $(99.7 \%)$ under unlubricated (dry) unidirectional sliding tests $\left(0,1 \mathrm{~m} / \mathrm{s}\right.$ to $12,0 \mathrm{~m} / \mathrm{s} ; 22^{\circ} \mathrm{C}$ and $\left.400^{\circ} \mathrm{C}\right)$ as well as in oscillation tests $(\mathrm{f}=20 \mathrm{~Hz}, \Delta \mathrm{x}=0,2 \mathrm{~mm}, 2 / 50 / 98 \%$ rel. humidity, $\mathrm{n}=$ $10^{5} / 10^{6}$ cycles). Microstructure and phase compositions were determined as well. The tribological data obtained were benchmarked with different ceramics, cermets, hard metals and thermally sprayed coatings, where $\mathrm{NbC}$ bonded with $8 \%$ and $12 \%$ Co presented above $8 \mathrm{~m} / \mathrm{s}$ the lowest wear rates so far in such a benchmark. Binderless $\mathrm{NbC}$ (HP-NbC1) and the metal bonded $\mathrm{NbCs}$ exhibited low wear rates under dry sliding associated with high P.V load carrying capacities. NbC-based hard metal bonded with 12 vol.- $\%$ of $\mathrm{Fe}_{3} \mathrm{Al}$ resulted in a higher hardness level than for 12 vol.-\% cobalt. The tribological profile established revealed a strong position of $\mathrm{NbC}$ bearing materials under tribological considerations and for closed tribosystems against established reference tribo-couples.
\end{abstract}

Keywords: Sliding; Friction; Wear; Ceramic; Oscillation; NbC; Niobium carbide; Cobalt; $\mathrm{Fe}_{3} \mathrm{Al}$; Hard metal; Strength; Modulus; High temperatures.

1 Head of division 6.3 "Tribology\&Wear Protection", BAM Federal Institute for Materials Research and Testing, DE-12200 Berlin, Germany.

2 Managing director, Niobelcon BVBA, BE-2970 Schilde, Belgium.

\footnotetext{
* Technical contribution to the 2nd International Brazilian Conference on Tribology - TriboBR 2014, November $3^{\text {rd }}$ to $5^{\text {th }}$, 2014, Foz do Iguaçu, PR, Brazil.
} 


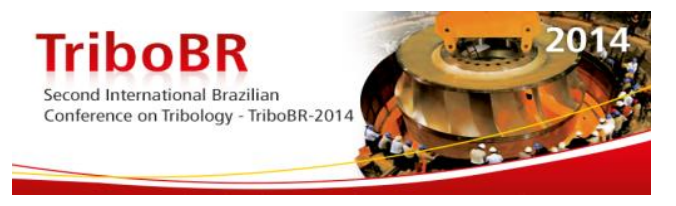

\section{INTRODUCTION}

Historically, tungsten carbide (WC) has dominated the market for wear resistant materials including cutting tool materials. Hard metals and tungsten carbide stand synonymously with wear resistance.

Approximately $80 \%$ of the global tungsten production is mined in China, yielding an annual total of 75.000 tons. Niobium, a refractory metal like tungsten, offers a possibility in partially or even fully substituting tungsten in hard metals, thermally sprayed coatings, claddings and wear resistant castings. The monocarbide $\mathrm{NbC}$ has a melting point of $3.520^{\circ} \mathrm{C}$ in comparison to the $2.870^{\circ} \mathrm{C}$ of WC.

Although niobium carbide has been well known for decades, knowledge of its property profile remained limited. Its poor sintering ability and very high sintering temperatures may explain why little research has been done on this material. These obstacles can now be overcomed by either hot pressing, high-frequency induction heated sintering or by plasma-spark sintering (SPS). On the other hand, demand for niobium has increased significantly over the last 45 years to a volume of $\sim 85.000$ tons, particularly as a microalloying element in high strength structural and automotive steels, stainless steels and alloys for petrochemical industry. In such alloys, niobium forms dispersed micro- or nano-sized niobium carbide precipitates, controlling the microstructure and thus improving mechanical properties [1,2] and the resistance against hydrogen embrittlement.

Yet, mechanical and particularly tribological properties of $\mathrm{NbC}$ remain largely unexplored. From an a priori contemplation, $\mathrm{NbC}$ is expected to be superior to $\mathrm{WC}$ in cutting tool applications, because at $1.225^{\circ} \mathrm{C} \mathrm{NbC}$ is nearly insoluble in $\mathrm{Cr}$, $\mathrm{Ni}$, Co or $\mathrm{Fe}[3,4]$, whereas WC is fully soluble under the same conditions. The high solubility of WC in these metals is responsible for the chemical wear of WC.

Recent studies [5] on hot-pressed (binderless) NbC (HP-NbC1) indicated, that pure niobium carbide has a high intrinsic wear resistance, when benchmarked against differrent ceramics, cermets, hard metals and thermally sprayed coatings. HP-NbC as such is quite brittle. Consequently, the addition of cobalt binder will improve properties, such as toughness and strength [6].

\section{EXPERIMENTAL PROCEDURE}

The binderless and metal bonded $\mathrm{NbCs}$ were elaborated using stoichiometric $\mathrm{NbC}$ powders. Different types of test samples for tribological and mechanical testing were prepared from disks by means of electrical discharge machining (See Figure 1). The planar surfaces of the tribological samples were finished by lapping or by polishing. The powders for densification of binderless (HP-NbC1) and cobalt as well as $\mathrm{Fe}_{3} \mathrm{Al}$ bonded $\mathrm{NbC}$ were pure and essentially free of tantalum. The non-commercial powder for HP$\mathrm{NbC} 1$ had a carbon content of $11,45 \pm 0,65 \mathrm{wt} .-\%$ carbon. The details of the mechanical and metallurgical features for hot-pressed and binderless NbC (HP-NbC1) using NbC powder $\left(\mathrm{d}_{90}=18,12 \mu \mathrm{m}\right)$ from CBMM are disseminated in reference [5]. A commercial powder from Treibacher AG (NbC100, Austria; FSSS=1,18 $\mu \mathrm{m} ; 11,4 \pm 0,7$ wt.-\%.carbon) was used for the metal bonded NbCs.

The route of preparation of the $\mathrm{NbC}$ grades are detailed in the references [5-7] as well as the 4-point bending strengths. Application of SPS technology allowed reducing the sintering temperature (from $2.150^{\circ} \mathrm{C}$ for hot-pressing to $1.280^{\circ} \mathrm{C}$ ) and sintering time

\footnotetext{
* Technical contribution to the $2^{\text {nd }}$ International Brazilian Conference on Tribology - TriboBR 2014, November $3^{\text {rd }}$ to $5^{\text {th }}$, 2014, Foz do Iguaçu, PR, Brazil.
} 


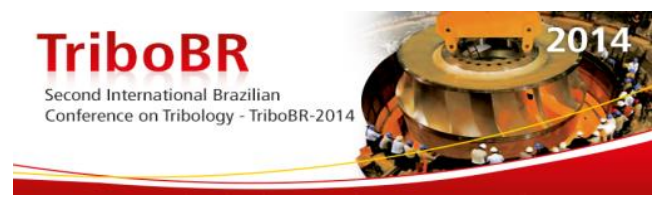

(from $4 \mathrm{~h}$ to $4 \mathrm{~min}$.), as will be shown in the present paper. The Figure 2 presents the microstructures and the phase composition by X-ray diffraction (XRD).

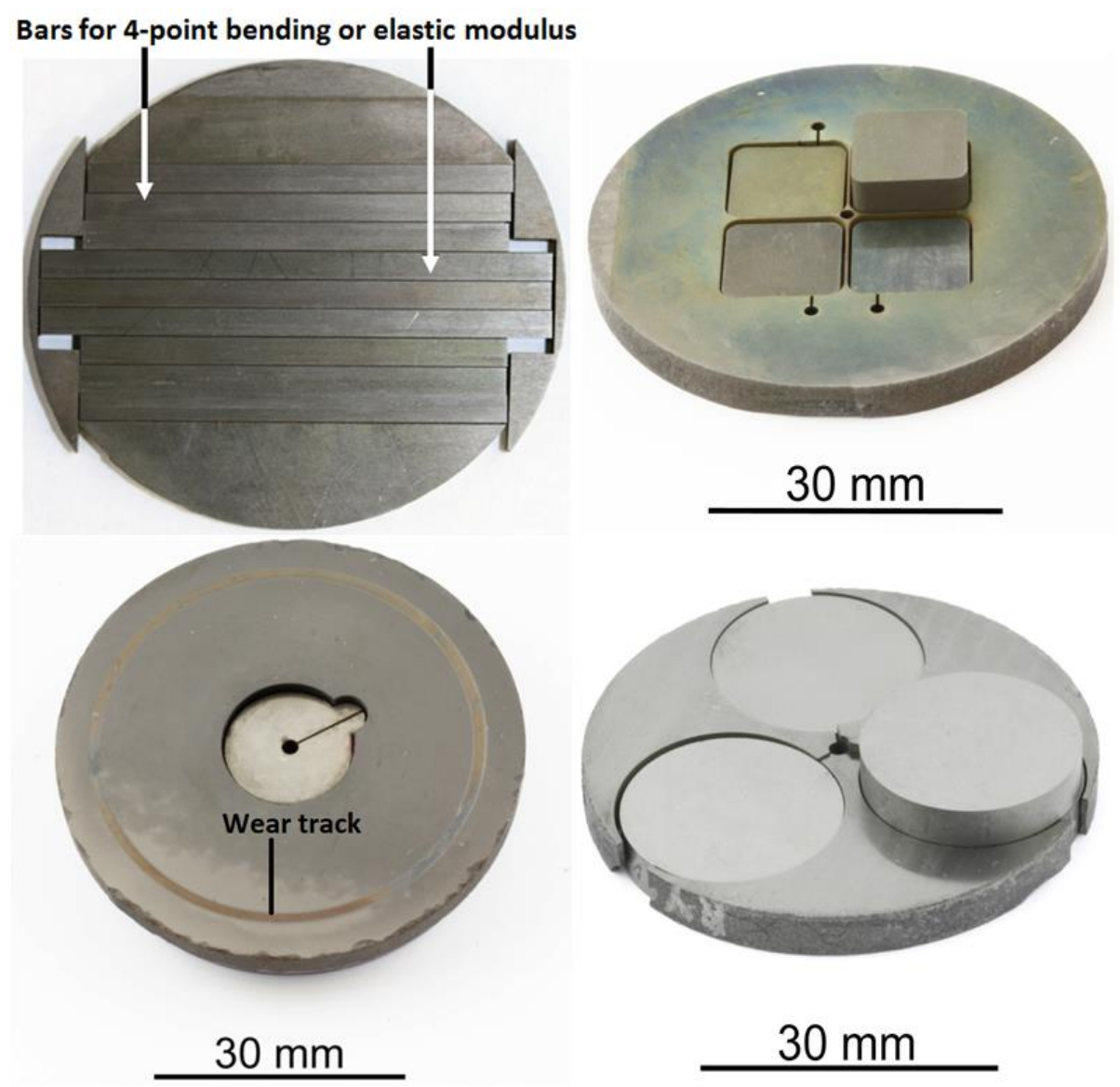

Figure 1. Different samples machined by electro-discharge from disks; top: left for mechanical testing and right for cutting inserts; bottom: left for continuous and right for oscillating sliding.

Bonding $\mathrm{NbC}$ with cobalt resulted in an average micro-hardness of $1.412 \pm 51 \mathrm{HV} 0.2$ for $\mathrm{NbC}-8 \mathrm{Co}$ and $1.410 \pm 13 \mathrm{HV} 0.2$ for NbC-12Co. Micro-hardness is considerably higher in $\mathrm{NbC}-12 \mathrm{Fe}_{3} \mathrm{Al}(1.633 \pm 50 \mathrm{HV} 0.2)$ and in HP-NbC1 (1.681 $\pm 92 \mathrm{HV0.2)}$ [5-7]. When performing HV5 measurements the $\mathrm{Fe}_{3} \mathrm{Al}$ as intermetallic phase bonded $\mathrm{NbC}-12 \mathrm{Fe}_{3} \mathrm{Al}$ appears to have a higher hardness $(1.448 \pm 32 \mathrm{HV} 5)$ than the binderless HP-NbC1 $(1.380 \pm 35$ HV5) as seen in references [5-7]. NbC-based hard metal bonded with 12 vol.-\% of $\mathrm{Fe}_{3} \mathrm{Al}$ resulted in a higher hardness level than for 12 vol.-\% cobalt at any indentation load. The $\mathrm{NbC}$ grades showed a strong load influence of micro-hardness for binderless $\mathrm{NbC}$, which is well established in literature and similarly applies for $\mathrm{WC}, \mathrm{W}_{2} \mathrm{C}$, $\mathrm{V}_{8} \mathrm{C}_{7}$ or $\mathrm{Mo}_{2} \mathrm{C}$ [7]. The effect is due to plastic deformation at room temperature under indentation via dislocation movements. In cubic carbides [8], the motion of dislocations occurs along the $\{111\}$ planes in the direction $\langle 110\rangle$.

The WC-6Ni (E204; C7P) used for comparison in the oscillating tests was from Sandvik Hard Materials and had a micro-hardness of $1.482 \pm 40 \mathrm{HV} 0.2$.

\footnotetext{
* Technical contribution to the $2^{\text {nd }}$ International Brazilian Conference on Tribology - TriboBR 2014, November $3^{\text {rd }}$ to $5^{\text {th }}$, 2014, Foz do Iguaçu, PR, Brazil.
} 

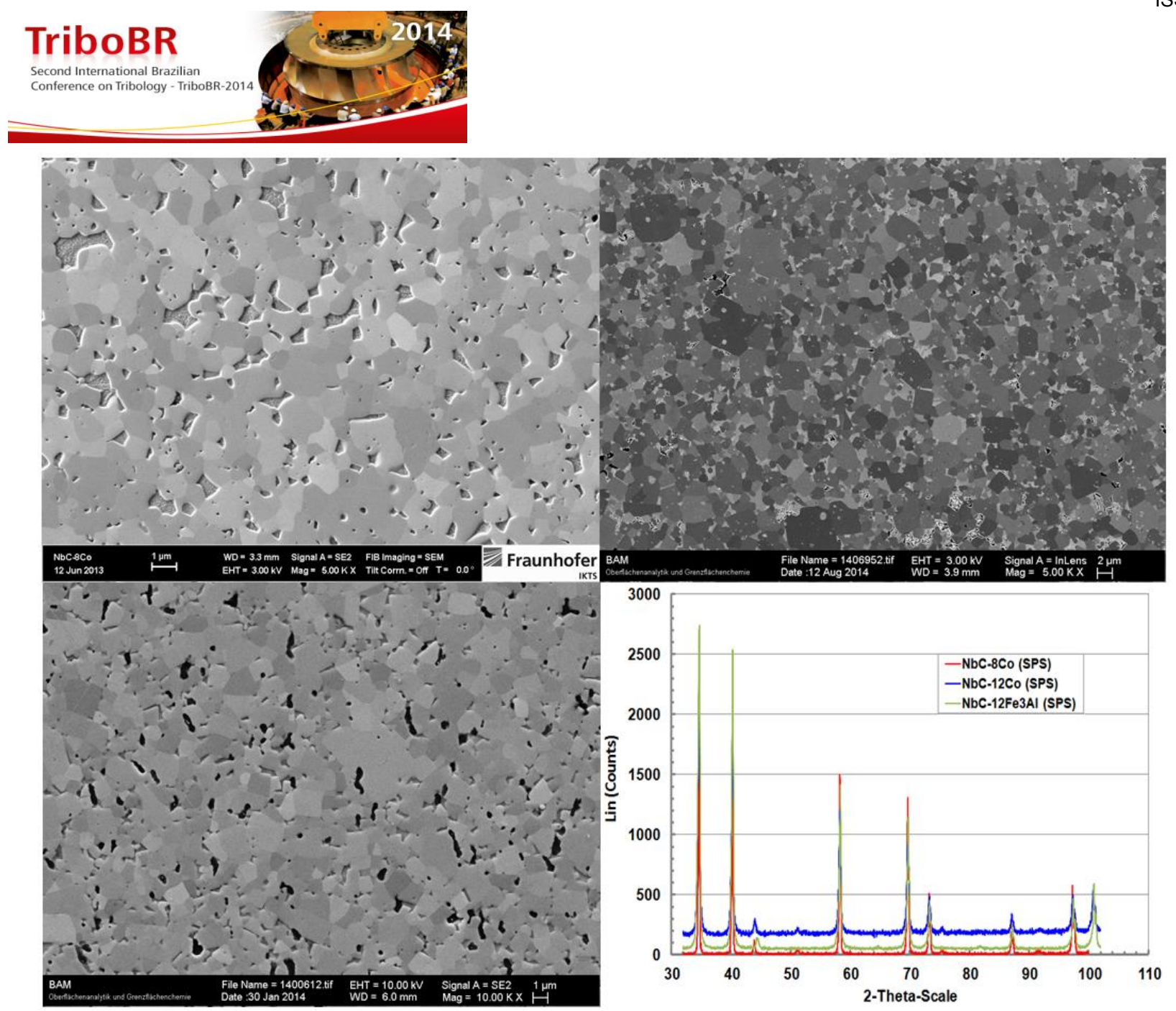

Figure 2. Microstructure of $\mathrm{NbC}-8 \mathrm{Co}$ (FESEM, top left), of $\mathrm{NbC}-12 \mathrm{Co}$ (top right) and of $\mathrm{NbC}-12 \mathrm{Fe}_{3} \mathrm{Al}$ (SEM, bottom left) and XRD diffraction diagrams (bottom right) of bonded $\mathrm{NbCs}$ ( $\mathrm{NbC}-8 \mathrm{Co}, \mathrm{NbC}-12 \mathrm{Co}$ and $\left.\mathrm{NbC}-12 \mathrm{Fe}_{3} \mathrm{Al}\right)$.

The tribometers for unidirectional sliding $[9,10]$ and oscillating [11] sliding are proprietary developments of BAM and the details are disclosed elsewhere. They comply with ASTM G99 (DIN 50324) and with DIN EN 1071-13:2010. Sintered alumina (99,7\%) bodies were used as stationary spherical (toroids with $R_{1}=21 \mathrm{~mm}$ and $R_{2}=21 \mathrm{~mm}$ ) specimens with polished surfaces $\left(R_{p k}=0,019 \mu \mathrm{m}\right)$, which were pressed against the planar surfaces of the rotating $\mathrm{NbC}$. The polished balls $(\varnothing=10 \mathrm{~mm}$; alumina $99.7 \%$ or $100 \mathrm{Cr} 6 \mathrm{H}=\mathrm{SAE}$ E52100) oscillated on top of a disk in the oscillating tribometer. The wear volumes of stationary and rotating/oscillating specimen were calculated from stylus profilometry and the wear scar diameters by using ASTM D7755-11. The wear rate $\mathrm{k}_{\mathrm{v}}$ is defined as the ratio of volumetric wear to the product of load $F_{n}$ and the sliding distance $s$. The coefficient of friction (CoF) and the total linear wear of both tribo-elements (specimen) were recorded continuously. One test per combination of parameters was performed, because the testing philosophy at BAM is to screen over a wide range of operating conditions rather than doing repeated tests, except at specific points.

\section{TRIBOLOGICAL RESULTS}

The following tribological data under dry friction were compared with homologous results issued from the tribological data base TRIBOCOLLECT of BAM for thermally sprayed

\footnotetext{
* Technical contribution to the 2nd International Brazilian Conference on Tribology - TriboBR 2014, November $3^{\text {rd }}$ to $5^{\text {th }}$, 2014, Foz do Iguaçu, PR, Brazil.
} 


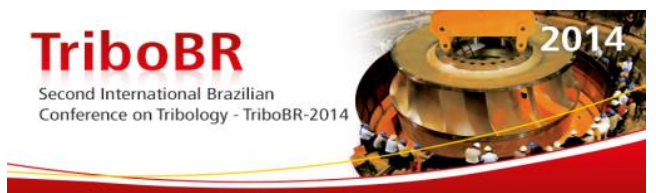

coatings [10,12], self-mated ceramics, ceramic composites [13] and steels as well as mated with stationary specimen in alumina. The tribological characteristics of these materials are summarized in [14]. The colored areas indicate the ranges established with different grades of the indicated material system.

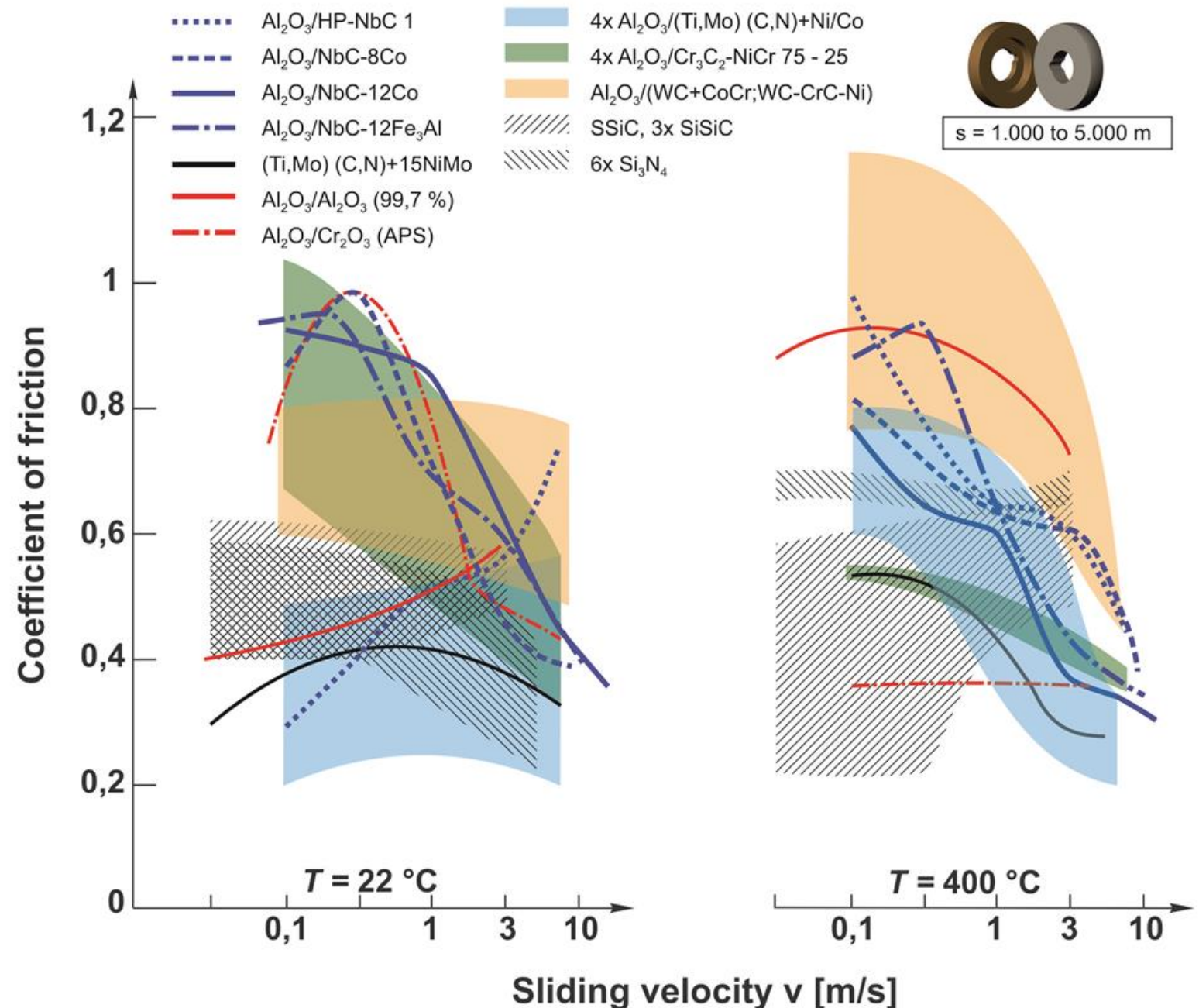

Figure 3. Coefficient of friction of $\mathrm{HP}-\mathrm{NbC1}$ and of cobalt or $\mathrm{Fe}_{3} \mathrm{Al}$ bonded $\mathrm{NbCs}$ compared to different ceramics and hard metals $[9,12,14]$ under dry friction at $\mathrm{RT}$ and $400^{\circ} \mathrm{C}$.

\subsection{Dry Sliding}

The frictional level of $\mathrm{NbC}$ grades in Figure 3 compares well with different tungsten carbide based or $\mathrm{Cr}_{2} \mathrm{C}_{3}$-based hard metals or monolithic alumina and thus qualifies these for traction \& frictional applications rather than for low friction bearings. At RT, the friction of HP-NbC1 increased with increasing sliding speeds, whereas metal bonded $\mathrm{NbCs}$ presented an opposite trend, where the tribo-oxidation of the binders dominated. At $400^{\circ} \mathrm{C}$, the friction decreased for all $\mathrm{NbC}$ grades and hard metal grades with increasing sliding speed, but were on average lower than those for WC grades. The friction of $\mathrm{NbC}$ grades at high sliding speeds was lowest at $400^{\circ} \mathrm{C}$. Low friction at high sliding speed is a favorable property for a cutting tool, reducing the cutting forces, thus achieving a given cutting performance at reduced machine power.

* Technical contribution to the $2^{\text {nd }}$ International Brazilian Conference on Tribology - TriboBR 2014, November $3^{\text {rd }}$ to $5^{\text {th }}$, 2014, Foz do Iguaçu, PR, Brazil. 


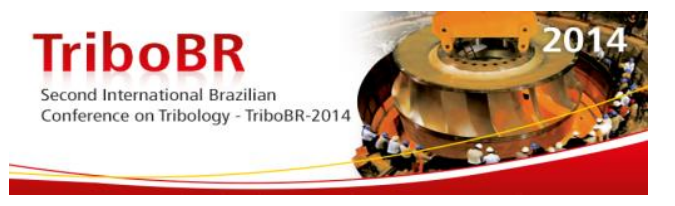

Figure 4 illuminates the total wear rate (sum of stationary $\left(\mathrm{Al}_{2} \mathrm{O}_{3}\right)$ and rotating $(\mathrm{NbC})$ specimen). HP-NbC1 comprised a particularly high wear resistance, especially at RT, which is more or less independent of sliding velocity. The wear resistance of HP-NbC1 at RT and low speeds is one of the highest. The metal bonded $\mathrm{NbC}$ grades at RT displayed a rather constant evolution of the wear rate with increasing sliding speed. The wear rates of the metal bonded $\mathrm{NbCs}$ decreased with sliding speed by one order of magnitude to low wear rates at high sliding speeds. At $8 \mathrm{~m} / \mathrm{s}$ at RT, the wear rates $\mathrm{kv}_{\mathrm{v}}$ of the rotating disk in $\mathrm{NbC}-8 \mathrm{Co}$ were outstandingly low with $\mathrm{kv}=4,4 / 7,8 \cdot 10^{-7} \mathrm{~mm} 3 / \mathrm{N} \cdot \mathrm{m}$, when compared to all other ceramics and hard metals. The wear rates of the rotating disks made from $\mathrm{NbC}-12 \mathrm{Co}$ reached values of $\mathrm{kv}=9,6 \cdot 10^{-7} \mathrm{~mm} / \mathrm{N} \cdot \mathrm{m}$ at $\mathrm{RT}$ and $12 \mathrm{~m} / \mathrm{s}$.

At $400^{\circ} \mathrm{C}$, the dry sliding wear resistances of tribo-active materials $\left(\mathrm{Tin}_{n-2} \mathrm{Cr}_{2} \mathrm{O}_{2 n-1}\right.$-phases, $(\mathrm{Ti}, \mathrm{Mo})(\mathrm{C}, \mathrm{N})$ ), binderless $\mathrm{HP}-\mathrm{NbC} 1$, metal bonded $\mathrm{NbCs}$ and thermally sprayed $\mathrm{Cr}_{2} \mathrm{O}_{3}$ or WC-based hard metals ranged between $10^{-7} \mathrm{~mm}^{3} / \mathrm{N} \cdot \mathrm{m}$ to $5 \cdot 10^{-6} \mathrm{~mm} / \mathrm{N} \cdot \mathrm{m}$ on a level known from the regime of mixed/boundary lubrication. Wear resistance under dry sliding of $\mathrm{NbC}$ grades is better than that of $\mathrm{Cr}_{3} \mathrm{C}_{2}$ and similar to or better than that of WC-based systems.

The load carrying capacity expressed as P.V values (contact pressure times sliding velocity), for all $\mathrm{NbC}$ grades increased at room temperature from $1-2 \mathrm{MPa} \cdot \mathrm{m} / \mathrm{s}$ at $0,1 \mathrm{~m} / \mathrm{s}$ up to $100 \mathrm{MPa} \cdot \mathrm{m} / \mathrm{s}$ above $8,0 \mathrm{~m} / \mathrm{s}$, because tribo-oxidation was enhanced with increasing sliding speed (or generated frictional heat). In contrast at $400^{\circ} \mathrm{C}$, the P.V values ranged more or less on the same level as at $\mathrm{RT}$. It is remarkable that the P.V values, or $\mu \cdot \mathrm{P} \cdot \mathrm{V}$, of these $\mathrm{NbC}$ grades increase with increasing sliding speed. $\mathrm{NbC}$ presented an unusually high load carrying capacity $[6,7]$.

Normally, the P.V values [15] of dry sliding couples decreased with increasing sliding speed. Triboactive materials [10,12], like $\mathrm{Ti}_{n-2} \mathrm{Cr}_{2} \mathrm{O}_{2 n-1}$ and $(\mathrm{Ti}, \mathrm{Mo})(\mathrm{C}, \mathrm{N})$, represent the nearest neighbor to $\mathrm{NbC}$ grades having slightly lower $\mathrm{P} \cdot \mathrm{V}$ values or maximum frictional heat flows. It has to be taken into consideration that $\mathrm{NbC}$ has a very high melting point $\left(3.522^{\circ} \mathrm{C}\right)$. Hot-pressed $\mathrm{Nb}_{2} \mathrm{O}_{5}$ is relatively soft and likely formed by tribo-oxidation on the $\mathrm{NbC}$, having a hardness of only $500 \mathrm{HV} 0.2$ and has a melting temperature of $1.512^{\circ} \mathrm{C}$ without sublimating. In contrast, $\mathrm{WO}_{3}$ formed by tribo-oxidation on WC begins to sublimate above $800^{\circ} \mathrm{C}$.

As can be seen in Figure 4, the wear resistance of cobalt and $\mathrm{Fe}_{3} \mathrm{Al}$ bonded $\mathrm{NbCs}$ at $\mathrm{RT}$ and high sliding velocities are the highest. The high melting point of $\mathrm{NbC}$ and of $\mathrm{Nb}_{2} \mathrm{O}_{5}$, when compared with WC and the sublimation of $\mathrm{WO}_{3}$, represent a tribological advantage under high temperature conditions at the cutting edge of a tool according to the shown wear resistances.

The wear tracks of $\mathrm{HP}-\mathrm{NbC1}$ obtained at $\mathrm{RT}$ and $400^{\circ} \mathrm{C}$ are represented in reference [5]. $\mathrm{NbC}$ is a beneficial material for closed tribosystems under dry sliding, because no wear particles visibly agglomerated in the wear tracks. The observation, that no agglomerates were found in the wear tracks is in line with the low wear rates of $10^{-6} \mathrm{~mm}^{3} / \mathrm{N} \cdot \mathrm{m}$.

\footnotetext{
* Technical contribution to the 2nd International Brazilian Conference on Tribology - TriboBR 2014, November $3^{\text {rd }}$ to $5^{\text {th }}$, 2014, Foz do Iguaçu, PR, Brazil.
} 


\section{TriboBR
Second International Brazilian
Conference on Tribology- TriboBR-2014}

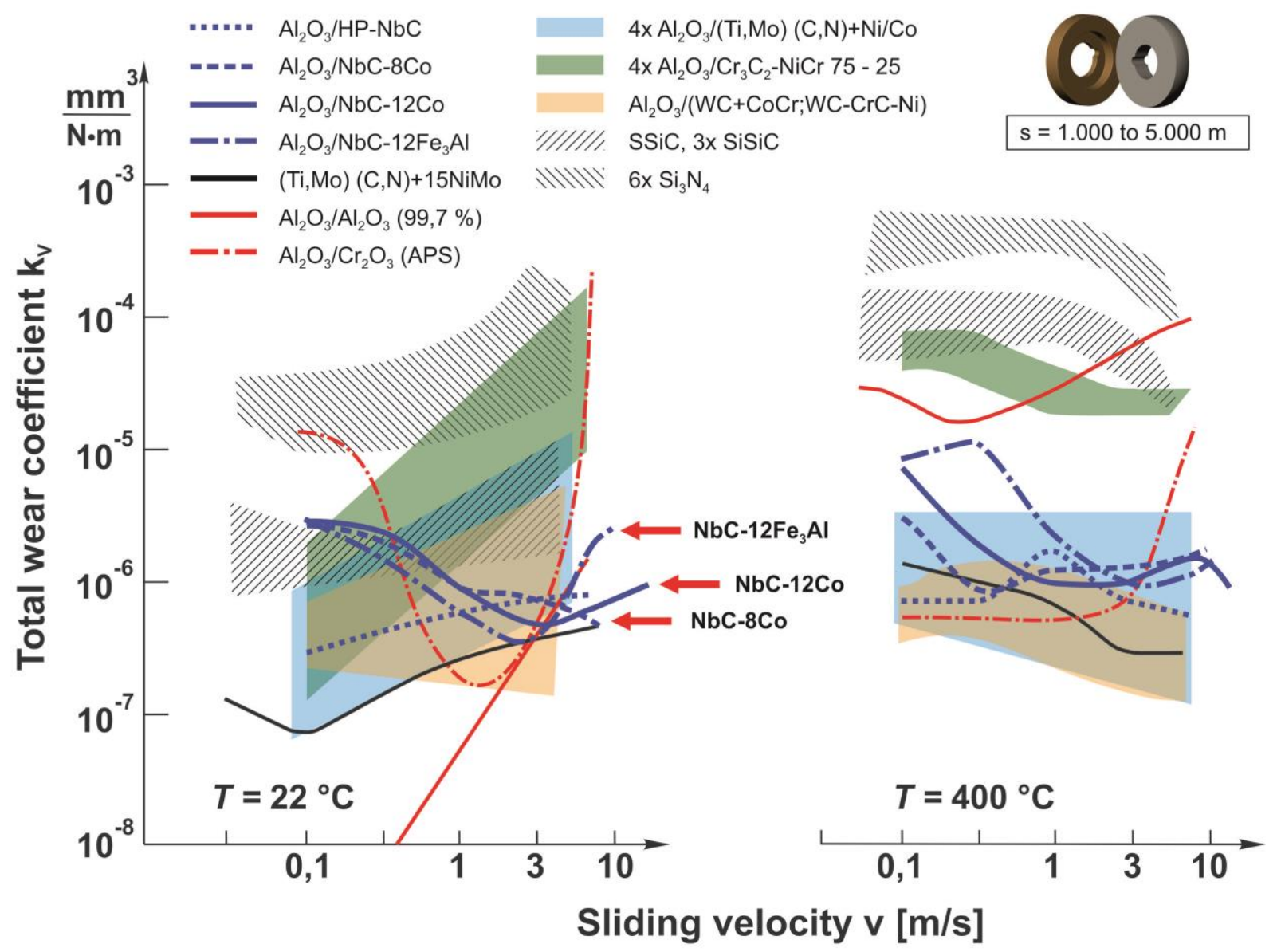

Figure 4. Total wear rates (right) of $\mathrm{HP}-\mathrm{NbC1}$ and of cobalt or $\mathrm{Fe}_{3} \mathrm{Al}$ bonded $\mathrm{NbCs}$ compared to different ceramics and hard metals $[9,12,14]$ under dry friction at RT and $400^{\circ} \mathrm{C}$

\subsection{Dry Oscillation}

The tribological profile (wear rate as " $\mathrm{K}_{\mathrm{v}}$ " versus coefficient of friction as "CoF") is displayed separately for polished counterbodies of alumina in Figure 5 and for ball bearing steel (100Cr6, SAE E52100) in Figure 6. The arrows indicate the effect of increasing the relative humidity from $2 \%$ to $98 \%$. The tribological profiles of steels and the ceramic samples including WC-6Ni, HP-NbC1 as well as cobalt and $\mathrm{Fe}_{3} \mathrm{Al}$ bonded $\mathrm{NbCs}$ are sensitive to relative humidity. The degree and the trend depend on the counterpart either in the case of the polished alumina ball $(\varnothing=10 \mathrm{~mm})$ or of the polished $100 \mathrm{Cr} 6(\varnothing=10 \mathrm{~mm})$. In contrast, the wear rates and coefficients of friction of binderless $\mathrm{NbC}$ (here: $\mathrm{HP}-\mathrm{NbC} 1$ ) are practically insensitive to relative humidity when oscillating against $100 \mathrm{Cr} 6$. In $100 \mathrm{Cr} 6$ steel or other ferrous alloys, tribo-oxidative [16] formation of $\mathrm{Fe}_{2} \mathrm{O}_{3}$ and/or hydrolyzed to $\alpha-, \beta$ - or $\gamma-\mathrm{FeOOH}$ and $\mathrm{Fe}(\mathrm{OH})_{2}$ dominate under dry oscillation at RT. Generally, and particularly in comparison to polished WC-6Ni, the wear resistance of $\mathrm{NbC}$ grades under dry oscillation is high, having $\mathrm{K}_{v}$ values of $10^{-6} \mathrm{~mm}^{3} / \mathrm{N} \cdot \mathrm{m}$.

\footnotetext{
* Technical contribution to the 2nd International Brazilian Conference on Tribology - TriboBR 2014, November $3^{\text {rd }}$ to $5^{\text {th }}$, 2014, Foz do Iguaçu, PR, Brazil.
} 

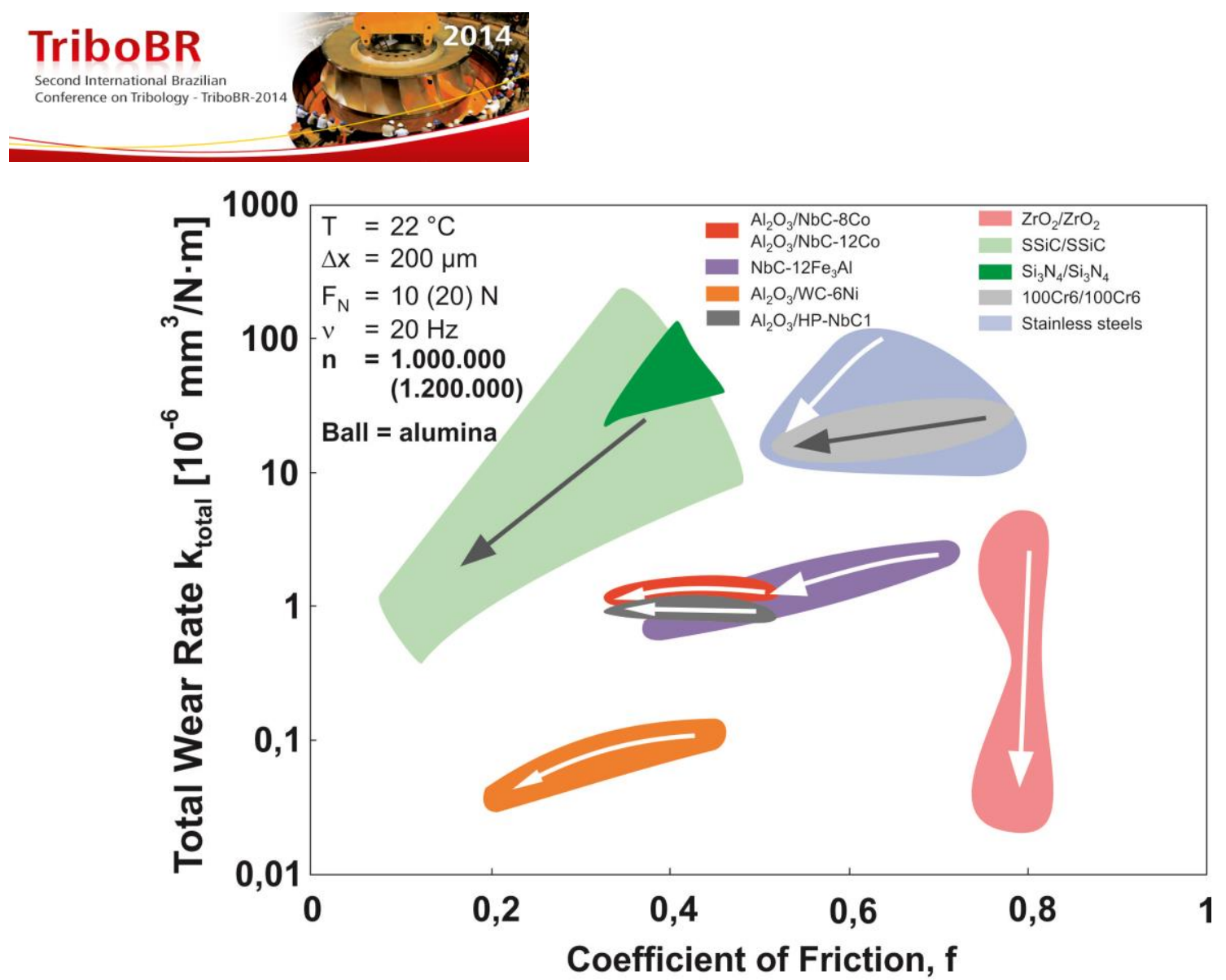

Figure 5. Total wear rates with the associated coefficient of friction of (balls= alumina) dry oscillation of different materials with the influence of the relative humidity

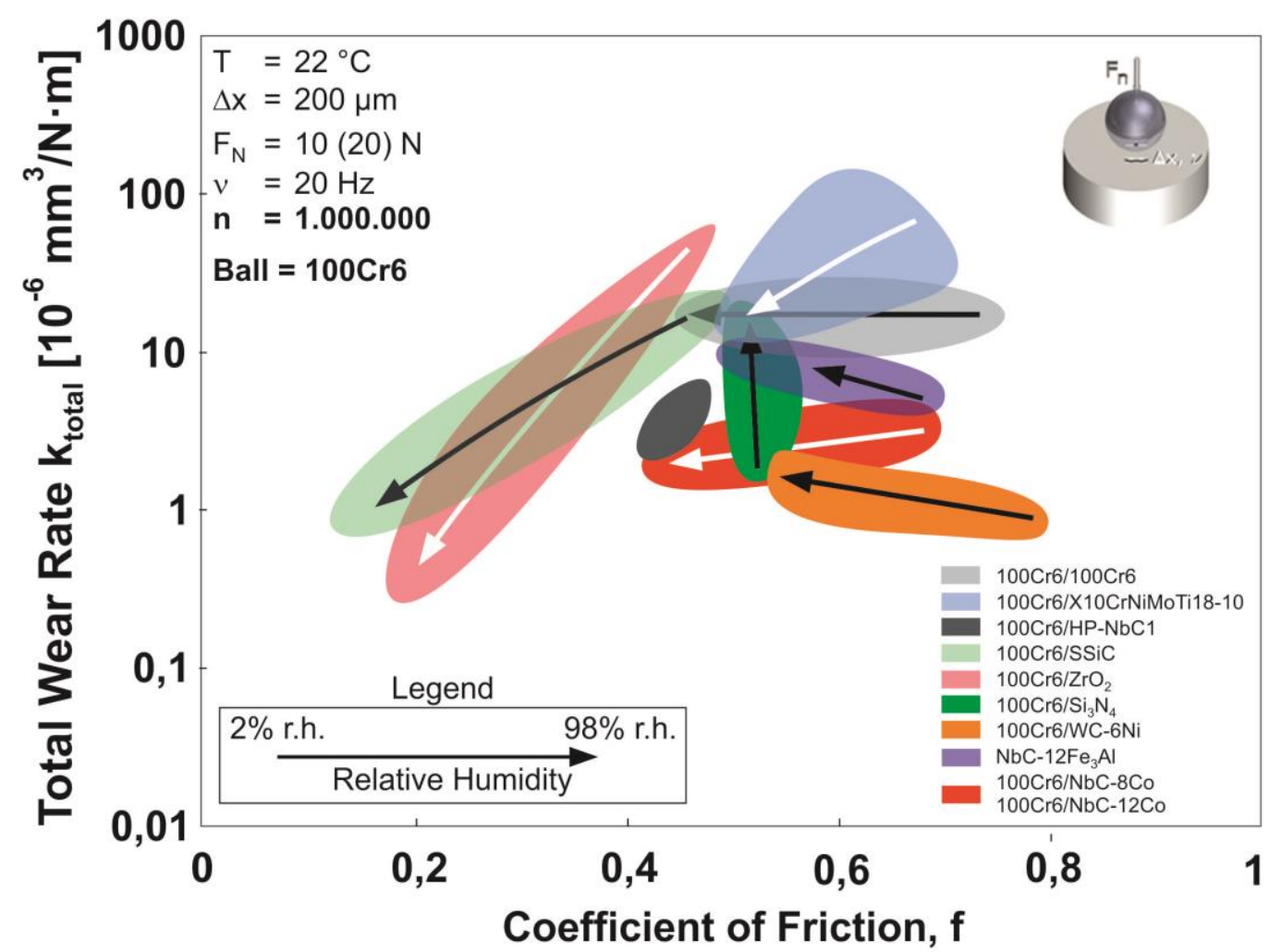

Figure 6. Total wear rates with the associated coefficient of friction (balls $=100 \mathrm{Cr} 6$ ) under dry oscillation of different materials with the influence of the relative humidity.

* Technical contribution to the $2^{\text {nd }}$ International Brazilian Conference on Tribology - TriboBR 2014, November $3^{\text {rd }}$ to $5^{\text {th }}$, 2014, Foz do Iguaçu, PR, Brazil. 


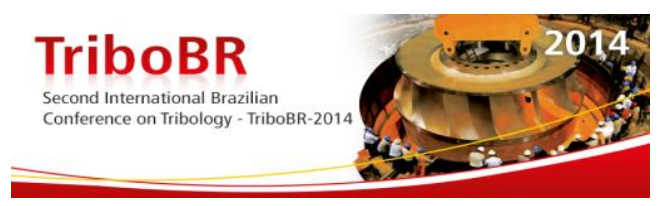

The wear rates under dry oscillation of binderless $\mathrm{NbC}(\mathrm{HP}-\mathrm{NbC} 1)$ and the cobalt bonded $\mathrm{NbC}$ grades are quite similar.

The presence of cobalt ( $\mathrm{NbC}-8 \mathrm{Co}$; $\mathrm{NbC}-12 \mathrm{Co}$ ) and $\mathrm{Fe}_{3} \mathrm{Al}$ binders (NbC-12Fe $\left.3 \mathrm{Al}\right)$ in $\mathrm{NbC}$ grades increases the sensitivity of their frictional behavior to relative humidity. The coefficient of friction decreases under increasing relative humidity. The wear rates remain unchanged for cobalt bonded $\mathrm{NbC}$. The $\mathrm{Fe}_{3} \mathrm{Al}$ binder further enhanced the influence of relative humidity on friction.

\section{CONCLUSIONS}

The wear resistance presented by binderless $\mathrm{NbC}$ and $\mathrm{NbC}$ grades bonded by cobalt or ironaluminide $\left(\mathrm{Fe}_{3} \mathrm{Al}\right)$ can easily compete with that of ceramics, "triboactive" materials and hard metals. Thus $\mathrm{NbC}$ qualifies as a member of the group of tribological materials with enhanced wear resistance. The room temperature wear rates of different $\mathrm{NbC}$ grades are low and less sensitive to increasing sliding speed. Remarkably, increasing sliding speeds to $8,0 \mathrm{~m} / \mathrm{s}$ and above decreases the wear rate down to outstandingly low values of $\mathrm{kv}$ of $2-7 \cdot 10^{-7} \mathrm{~mm}^{3} / \mathrm{N} \cdot \mathrm{m}$. The wear rates at $400^{\circ} \mathrm{C}$ of $\mathrm{NbC}$ grades generally remained below $10^{-6} \mathrm{~mm}^{3} / \mathrm{N} \cdot \mathrm{m}$, regardless of the applied sliding speed. The low wear rates of $\mathrm{NbC}$ were associated with high load carrying capacities ( $P \cdot V$-values), in excess of $100 \mathrm{MPa} \cdot \mathrm{m} / \mathrm{s}$. The P.V values increase with increasing sliding speed. Under dry oscillation, the wear resistance of binderles $\mathrm{NbC}$ was insensitive to relative humidity for bearing steel (100Cr6=SAE E52100) as well as alumina counterbodies, whereas the coefficient of friction of metal bonded $\mathrm{NbC}$ grades was reduced with increasing relative humidity indicating the impact or cobalt and $\mathrm{Fe}_{3} \mathrm{Al}$ binders. The low solubility of $\mathrm{NbC}$ in metals $[3,4]$ and the high P.V values are an ideal prerequisite for cutting tool materials. Furthermore, the achieved level in hardness and elastic modulus as well as the actual level in strength and toughness are sufficient to support the load at the cutting edge.

\section{Acknowledgements}

The assistance of Ms. Christine Neumann and Mr. Norbert Köhler for performing the tribological tests and profilometric analysis as well as of Mr. Steffen Glaubitz for the mechanical testing is gratefully acknowledged. Many thanks are addressed to Ms. Sigrid Binkowski, Ms. Sigrid Benemann and Mr. Maximilian Scheibe for carefully performing metallography, recording optical and SEM micrographs, as well as XRD. The authors are deeply indebted to Dr. Shuigen Huang from KU Leuven (Belgium) for producing the disks. The authors are grateful to Companhia Brasileira de Metallurgia e Mineração (CBMM), São Paulo, Brazil, for supporting this intensive test campaign.

\section{REFERENCES}

1 Mohrbacher $\mathrm{H}$, Zhai $\mathrm{Q}$. Niobium alloying in grey cast iron for vehicle brake discs. In: Proc. of Materials Science \& Technology Conf., October 16-20, 2011, Columbus, OHIO, ASM Int., pp. 434-445

2 Nylén T. Niobium in Cast Iron. In: Proc. of the Int. Symp. "Niobium Science and Technology", 2001, Orlando, TMS, 2001, ISBN 0-9712068-0-5, pp. 1063-1080

* Technical contribution to the $2^{\text {nd }}$ International Brazilian Conference on Tribology - TriboBR 2014, November $3^{\text {rd }}$ to $5^{\text {th }}$, 2014, Foz do Iguaçu, PR, Brazil. 


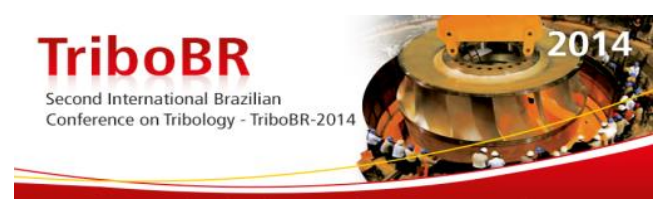

3 Edwards R, Raine T. The solid solubility of some stable carbides in cobalt nickel and iron at 1250. Pulvermetallurgie, Springerverlag, (1952), 232-242

4 Guha JP, Kolar D. Systems of Niobium Monocarbide with Transition Metals. Journal of the Less-Common Metals, 29 (1972) p. 33-40

5 Woydt M, Mohrbacher H. Friction and wear of binder-less niobium carbide. WEAR, Vol. 306, Issues 1-2, 2013, p. 126-130

6 Woydt M, Mohrbacher $\mathrm{H}$. The Use of Niobium Carbide $(\mathrm{NbC})$ as Cutting Tools and for Wear Resistant Tribosystems. Int. J. of Refractory Metals and Hard Materials, 2014,

7 Nino A. et al.. Indentation Size Effect for the Hardness of Refractory Carbides. Materials Transactions, 2010; 51(9): 1621 to 1626

8 Kurlov AS, Gusev Al. Effect of nonstoichiometry of NbCy and TaCy powders on their highenergy ball milling. Int. Journal of Refractory Metals and Hard Materials, 2014; 46: 125-136

9 Woydt M, Habig K.-H. High temperature tribology of ceramics. Tribology International 22 (1989) 75-88

10 Berger L.-M, Stahr CC, Saaro S, Thiele S, Woydt M, Kelling N. Dry sliding up to $7.5 \mathrm{~m} / \mathrm{s}$ and $800^{\circ} \mathrm{C}$ of thermally sprayed coatings of the $\mathrm{TiO}_{2}-\mathrm{Cr}_{2} \mathrm{O}_{3}$ system and (Ti,Mo) $(\mathrm{C}, \mathrm{N})$ $\mathrm{Ni}(\mathrm{Co})$. WEAR 267 (2009) 954-964

11 Klaffke D. Fretting Wear of Ceramics. Tribology International 22 (1989) 89-101

12 Berger L-M, Saaro S, Woydt M. (WC- $(\mathrm{W}, \mathrm{Cr})_{2} \mathrm{C}-\mathrm{Ni}$ - the unknown hardmetal coating. Thermal Spray Bulletin (2008) 39-42

13 Skopp A. and Woydt,M.. Ceramic and Ceramic Composite Materials with Improved Friction and Wear Properties. Tribology Transactions 38 (1995) 233-242

14 Woydt M. Tribologie des Céramiques (Tribology of ceramics), Encyclopédie. "Techniques de I’Ingénieur, Paris, March 2013, Tri 4550

15 Woydt M. Application des données tribologiques des matériaux (The use of tribological quantities of materials). Encyclopédie "Techniques de I'Ingénieur, Paris, June 2012, BM 7 006v2

16 Klaffke D. On the repeatability of friction and wear results and on the influence of humidity in oscillating sliding tests of steel-steel pairings. WEAR 189 (1995) 117-121.

* Technical contribution to the $2^{\text {nd }}$ International Brazilian Conference on Tribology - TriboBR 2014, November $3^{\text {rd }}$ to $5^{\text {th }}$, 2014, Foz do Iguaçu, PR, Brazil. 